\title{
Food offerings in graves from the Danubian Neolithic (5500-4900 B.C.) in the upper Rhine valley
}

\author{
Rose-Marie ARBOGAST \\ CNRS UMR 7044 - MISHA, \\ 5 allée du Général Rouvillois, \\ F-67083 Strasbourg cedex (France), \\ rose-marie.arbogast@misha.fr
}

KEY WORDS

Animal offering, grave, upper Rhine valley.
MOTS CLÉS

Dépôts alimentaires, sépulture,

Néolithique,
Arbogast R.-M. 2013. - Food offerings in graves from the Danubian Neolithic (5500-4900 B.C.) in the upper Rhine valley. Anthropozoologica 48 (2): 255-261. http://dx.doi.org/10.5252/ az2013n2a4

\begin{abstract}
Ranging from the valves of exotic marine shells (Spondylus) to anthropomorphic figurines fashioned on metapodials, and from carnivore tooth beads to the deposition of partial carcasses, the representation of fauna in the graves of the early Neolithic in northern France and in the upper Rhine valley takes very diverse forms. This contribution focuses on those remains which can be associated with the practice of food deposits in order to better define the modalities of this type of such finds (choice of species and body parts, preparation, arrangement and position in the grave), understand their meaning and outline their characteristics in relation to other categories of animal bone items (ornaments, tools...) which form part of the grave assemblage.
\end{abstract}

\section{RÉSUMÉ}

Dépôts alimentaires dans les sépultures néolithiques danubiennes (5500-4900 B.C.) de la plaine du Rhin supérieur.

Des valves de coquillages marins exotiques (spondyles), aux figurines anthropomorphes sur métapodes, de la parure sur dents de carnivores aux dépôts de parties de squelettes, la représentation de la faune dans les sépultures du Néolithique ancien dans le Nord de la France et dans la vallée du Rhin supérieur recouvre une gamme de vestiges très divers. Cette contribution s'attachera plus particulièrement aux restes témoignant de la pratique de dépots à valeur alimentaire, afin de saisir les caractéristiques de ce type de vestiges (choix des espèces et des quartiers, préparation, organisation et position dans l'espace funéraire), de percevoir leur signification et d'en préciser les caractéristiques par rapport aux autres catégories de vestiges osseux (parure, outillage...) qui composent le mobilier funéraire. 


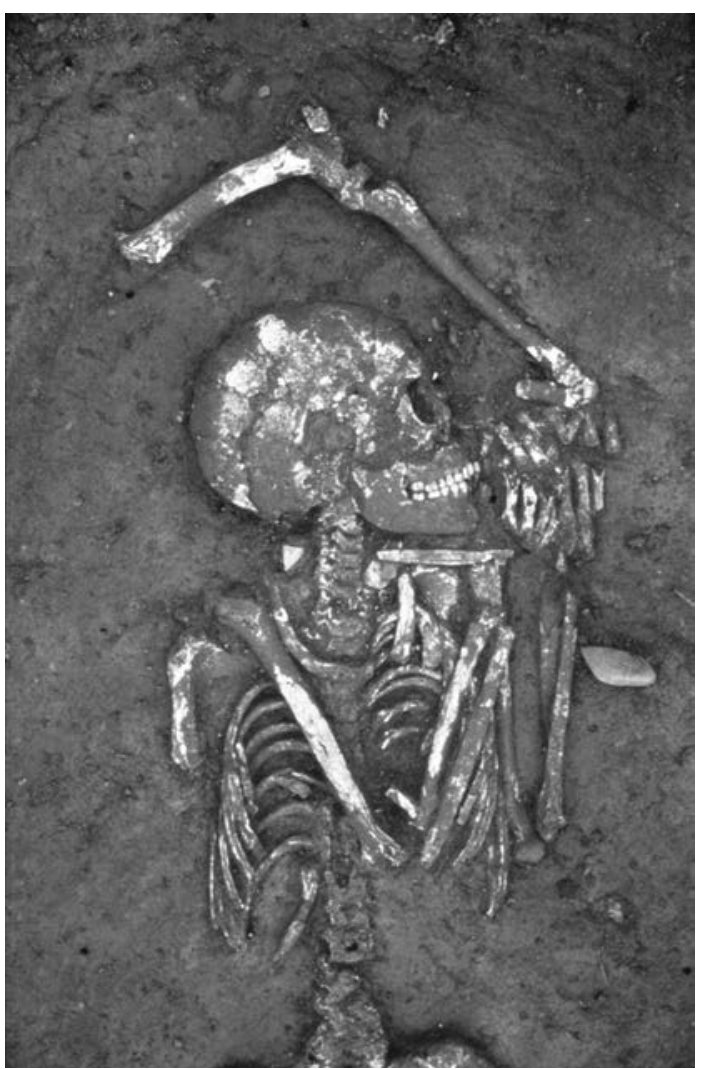

FIG. 1. - View of grave $n^{\circ} 90$ in the cemetery of Vendenheim with the deposit of a goat hind leg near the skull. Photo F. Schneikert (AFAN).

Animal bone remains are among the find categories most frequently associated with grave goods in the early Neolithic. They include remains with very diverse characteristics depending on whether they correspond to ornaments, tools, whole intact bones or even complete skeletons. This contribution more specifically addresses those remains which constitute food offerings in graves from the so-called Danubian Neolithic in the upper Rhine valley, and aims at describing and understanding the characteristics of such deposits (choice of species and of body parts preparation, arrangement and position within the grave) and understanding their meanings.

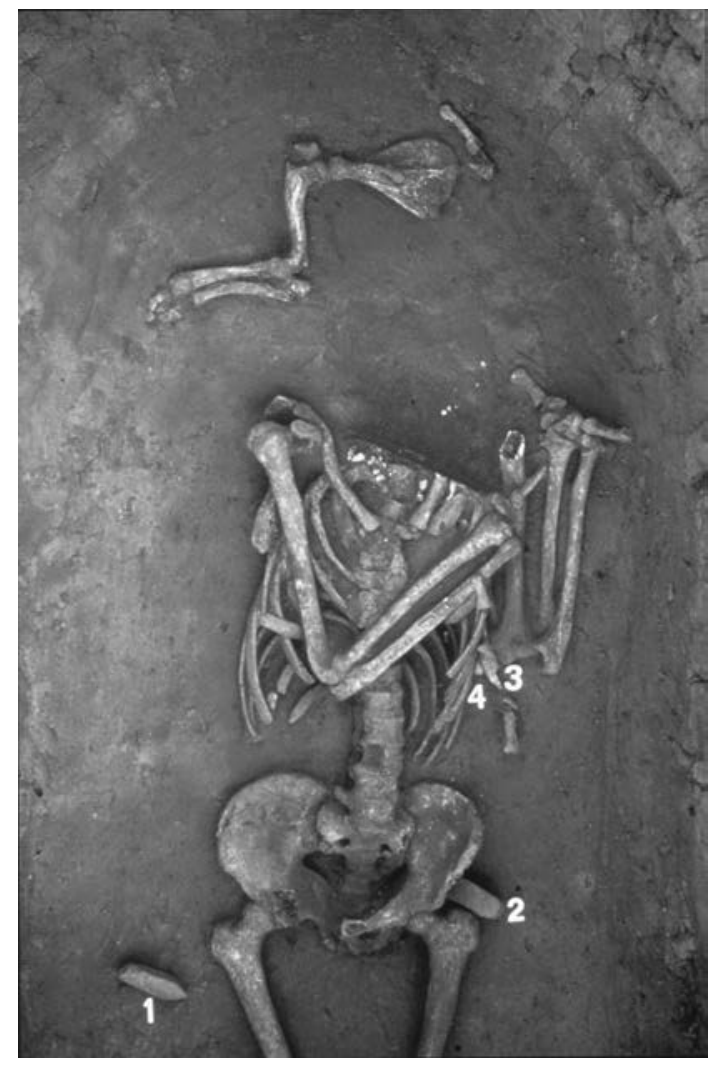

FIG. 2. - View of grave $n^{\circ} 94$ in the cemetery of Vendenheim with the deposit of a fore leg from a young Suinae near the skull. Photo F. Schneikert AFAN)

\section{FOOD OFFERINGS FROM EARLY NEOLITHIC BURIAL SITES IN ALSACE}

The discovery of whole animal skeletons or of skeletal elements (originally placed in anatomical connection) close to human remains is the clearest clue in favour of food offerings for the deceased. In the Linear Pottery Culture (LBK), such discoveries are rare. In the roughly twenty occurrences throughout Europe, the deposits mostly consist of skeletal parts (shoulders, legs) arranged close to the human skull. In addition, such deposits are only found in a few graves within burial sites, and they seem to correspond to a given level of wealth, as they are generally associated with particularly abundant grave goods. 
Sépulture 94

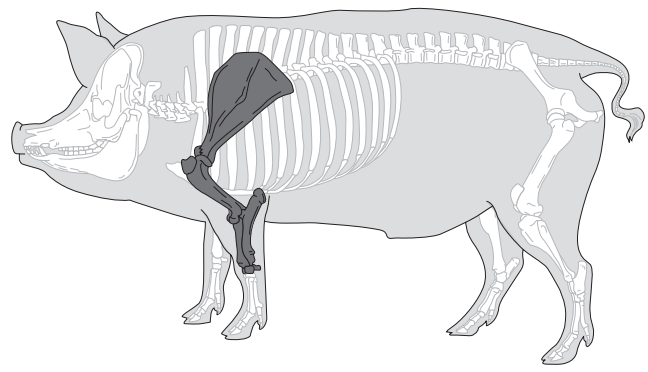

Sépulture 142

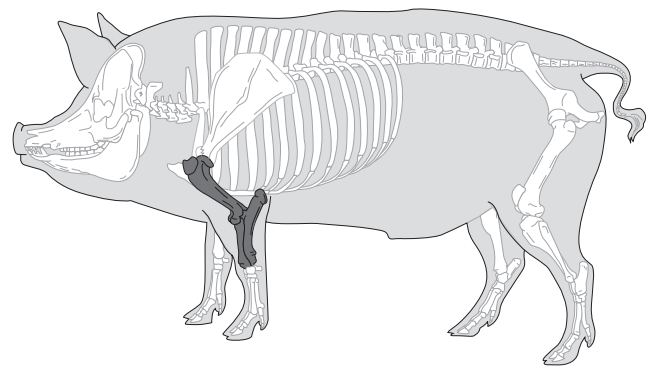

Sépulture 134
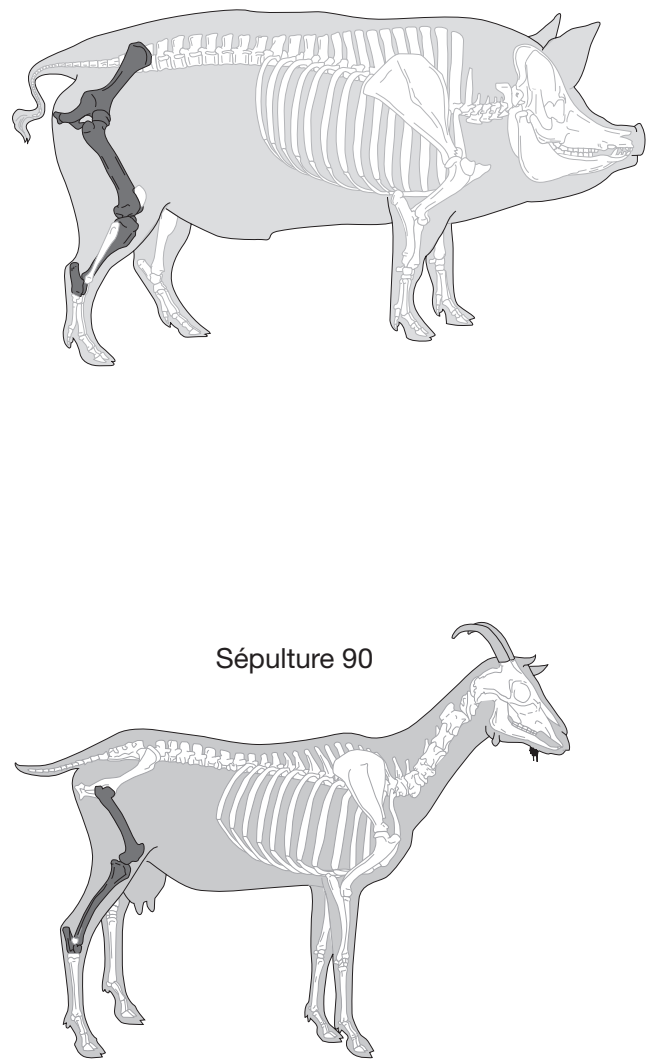

FIG. 3. - Drawing of the meat offering deposits in graves from the cemetery of Vendenheim "Les Hauts du Coteau", dated to a late phase of the Linear Pottery Culture.

Several recent discoveries are now available which offer the opportunity to re-analyse this practice and to better understand its meaning in early and middle Neolithic communities.

The burial site of Vendenheim "les Hauts du Coteau", excavated in 1999, contains 111 graves from the late Linear Pottery Culture (Jeunesse 2002, Boës et al. 2007), of which four contain bone deposits that can clearly be identified as food offerings. They consist of small assemblages of unbroken animal bones placed in close proximity to the human skull. Grave $n^{\circ} 90$ for example contained a femur, a tibia, a talus and a calcaneus of a juvenile goat (Capra hircus)(Fig. 1). Grave $\mathrm{n}^{\circ} 94$ contained a scapula, a humerus, a radius- ulna and three carpals of a young suinae (Sus scrofa sp.; Fig. 2). Grave $n^{\circ} 134$ contained a coxal bone, a femur, a tibia, a calcaneus and a talus and grave $\mathrm{n}^{\circ} 142$ a humerus and a radius-ulna, both from young suinae (Sus scrofa sp.). None of these bones corresponded to isolated remains, as they were systematically found in assemblages where articulations were preserved. They belong to the proximal parts of the limbs and therefore to the portions richest in meat (shoulder, leg), never to other elements such as the skull, distal limbs or trunk (Fig. 3). The precise selection of these elements is further emphasized by the exclusive choice of young animals. However, little information could be gathered about their preparation, 

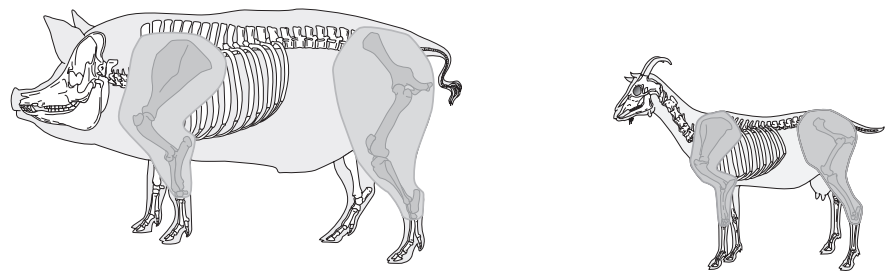

Trebur
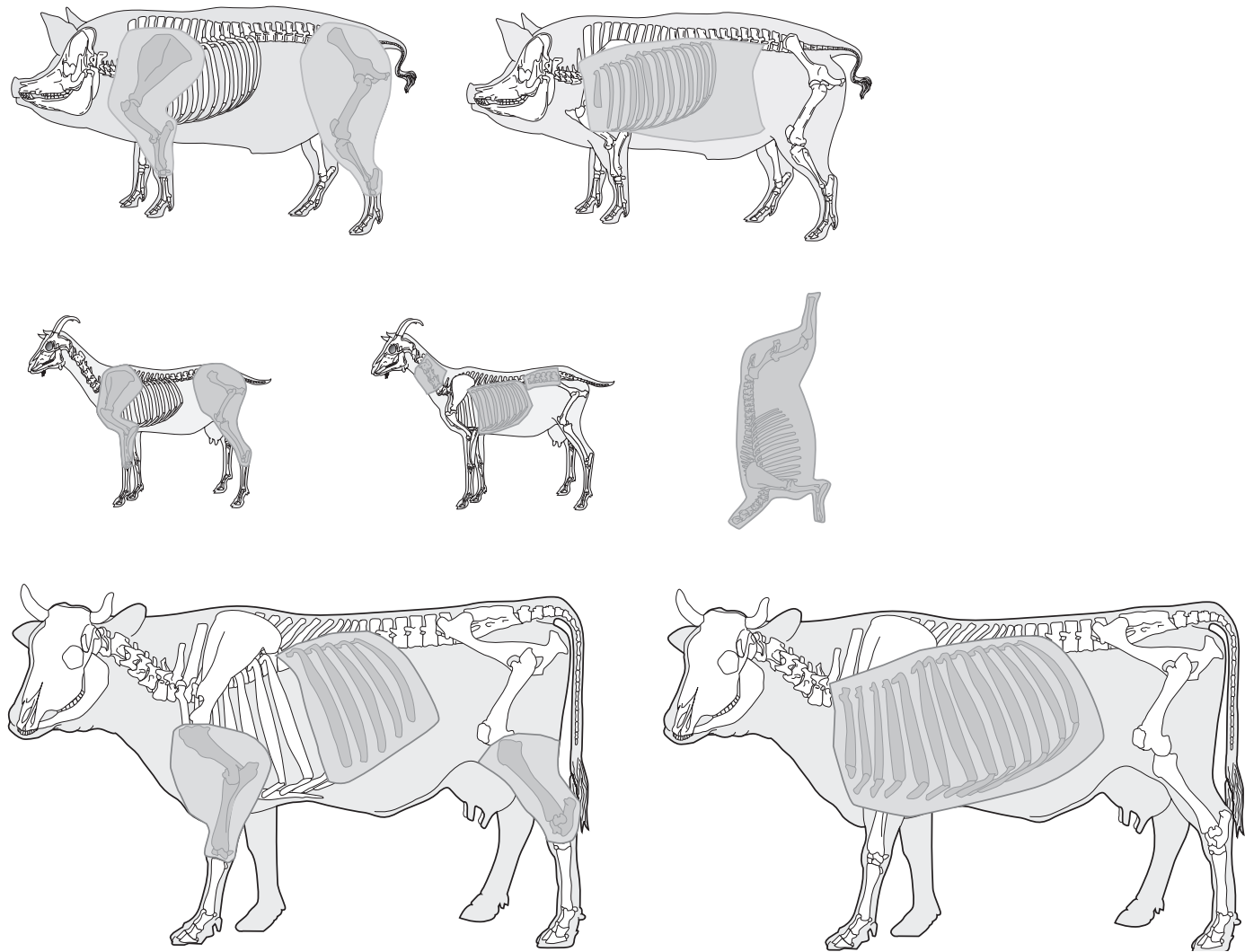

FIG. 4. - Schematic synthesis of the meat offering deposits in graves dated to the late phase of the Linear Pottery Culture and from the cemetery of Trebur (Germany), dated to the middle Neolithic (Hinkelstein and Grossgartach Cultures).

except for cut marks found on the goat leg femur (grave 90). Located on the proximal part of the diaphysis, just below the insertion point of the trochanter major, they are due to slicing between leg and pelvis rather than the removal of meat itself. This pattern differs from that of pork ham, in which the coxal is preserved. Differences also exist among joints of pork shoulders, as in grave 94 the scapula is preserved whereas in grave 142 it is not. As mentioned above, the choice of shoulders and legs from young animals underlines the qualitative features of these parts. Discrete cut 
marks which could correspond to the removal of meat were not seen. This could be due either to the poor preservation of bone surfaces, or to the fact that the meat was not sliced off. The way in which the positions of articulations are preserved, the presence of complete bones and the fact that the distance between bones perfectly corresponds to the former presence of flesh all indicate that these animal remains were originally deposited as meat pieces.

Other recent data about similar practices have been reported. For instance, in the recently excavated burial site of Ingenheim (Haut-Rhin), remains of food offerings were found in the graves of two adults. Badly preserved remains of a pork shoulder (radius, humerus and scapula) were found close to the human skull in grave $\mathrm{n}^{\circ} 281$. The tibia of a small ruminant, very likely from goat or sheep (Capra hircus/Ovis aries), was found on the upper limb of the individual buried in grave 393.

There are several similarities between these deposits and other excavations from the Linear Pottery Culture. The Bavarian burial sites of Aiterhofen and Dillingen produced three graves with food offerings: a goat or sheep leg (Aiterhofen, grave 94), a pork ham (Aiterhofen, grave 102) and the shoulder of a young domestic caprinae (Steinheim, grave 20; Nieszery, 1995). Comparable deposits are also reported for graves in Sondershausen (Kahlke, 1954), in Stuttgart-Mühlhausen and in Stephansposching (Schmotz, personal communication), but detailed descriptions are lacking. Those in Aiterhofen and in Steinheim reveal an identical selection of the richest portions (shoulders and hams), taken from young domestic animals and placed above the human skull. As in the Alsatian burial sites, such deposits are only found in few graves and associated with the wealthiest grave goods.

\section{THE DEPOSITS OF THE TREBUR BURIAL SITE (HINKELSTEIN AND GROSSGARTACH CULTURES)}

Some characteristics of the deposits found in the Linear Pottery Culture are also observed in the burial site of Trebur (Hessen) which with its 137 graves is the largest burial site of the Hinkelstein-Grossgartach cultural sequence (Spatz, 1999 ; Spatz \& von den Driesch 2001). In the oldest part of the site (Hinkelstein Culture), bone deposits are found in more than half the graves, whereas in the Grossgartach graves, the proportion is strongly reduced (five out of 58 graves). Convergences become evident if we consider the choice of the meat portions, with mainly pork legs (15 examples) and shoulders (three examples), as well as sheep/goat legs (five examples) and shoulders (five examples)(Fig. 4). As in Linear Pottery burial sites, these were preferentially taken from young domestic animals. They are mostly found placed near the skull of the deceased, but in a few cases they may be close to the upper limbs or ribcage. It is also striking that the composition of the deposits varies according to the sex of the deceased. For instance, pork is present in 14 out of 18 male graves, whereas only one such occurrence was observed for women. In female graves, sheep are more frequent. In addition, compared to Linear Pottery offerings, the choice of species differs, as in addition to sheep, goat and pork one can also find beef. Beef is absent in Linear Pottery graves, but occurs in 24 out of the 137 graves of the Trebur burial site. As for the other species, shoulders and legs are used, but also portions of the thorax which can contain only a few ribs or encompass the whole rib cage. They are mostly deposited on the deceased's upper limbs or close to the skull and can occasionally cover half the human skeleton. The wealth of these deposits is also attested by the presence, in about ten graves, of complete goat or sheep carcasses with only the head and limb tips missing. In rare cases complete or half skeletons of young animals, or even multiple deposits associating quarters with complete carcasses, constitute particularly rich assemblages. With only few exceptions, such deposits only comprise bones from domestic animals. Wild animals feature rarely, the only examples being three wild boar legs and a piece of red deer. The former could, however, be derived from wild boars (Sus scrofa scrofa) bred in captivity (Spatz \& von den Driesch, 2001), and the red deer (Cervus elaphus) fragment is limited to an isolated radius. It is probably not a food deposit, but should rather be grouped with the heterogeneous collection of isolated bones generally 
encountered in burial contexts (Jeunesse \& Arbogast 1997). Indeed, the red deer items present tend to be antler or tools, alongside rich ornaments made from teeth (canines), which suggests that in terms of grave goods, this animal carries a more symbolic meaning (Jeunesse 1997 \& 2002).

\section{STATUS OF BONE DEPOSITS.}

The bone deposits excavated from early and middle Neolithic graves in the upper Rhine valley share a number of characteristics which reflect a uniform tradition. Bones found in more or less important assemblages are the remains of animal portions deposited in the graves. Overall, the preservation of articulation features, the lack of slicing marks and presence of cut marks suggest that these were deposits of meat quarters. The composition of the deposits always belongs to those parts of butchered animals which are richest in meat (legs, shoulders etc). The preferential choice of young animals further underlines their qualitative aspect. The butchery value is also particularly emphasized in carcasses which retain no sign of the identity of the animal (no skull, extremities, no teeth...). The deposits are simply anonymous bodies, showing exclusively the properties of food, which in itself is very informative about the value attributed to animals in this culture. The fact that only domesticated animals are represented further underlines the economic value of husbandry, which could already be deduced from the animal assemblages available from settlements of the same period (Arbogast 1994). The composition of the grave deposits can thus be considered a transposition into death of the place that animals occupied among the living. When they are found in an individual grave, these deposits can be interpreted as food offerings to this person. As their size is far beyond what is needed for a single meal, such supplies should rather be considered a viaticum. What they tell us about the relationship between humans and animals is quite distinct from what we learn from other animal remains, such as ornaments and tools. Bone tools and ornaments made of hard animal material are rare in early Neolithic tombs, but more frequent in the middle Neolithic. In the
Trebur cemetery, they belong to the particularly wealthy grave assemblages. Highly appreciated in this context, teeth are privileged elements of head ornaments, of belts made of red deer teeth (canines), of bracelets made of suinae (Sus scrofa sp.) canines, or of pendants made of perforated dog (Canis familiaris), wild cat (Felis sylvestris), red fox (Canis vulpes) or badger (Meles meles) canines. Bone tools consist of awls on red deer metapodials and antlers. Such items use those teeth or extremities which had been discarded from food deposits, and are more related to the identity of the animal. Here the importance of wild animals does not reflect the economic value of hunting, which was very limited during this period (Jeunesse \& Arbogast 1997), but is rather symbolic and participates in the representation of the animal. The almost exclusively wild origin of these artefacts underscores the opposition to food offerings. Whereas the latter have a strictly economic meaning, wild animals offer a more symbolic dimension. These differences are however not solely linked to the wild vs. domestic status, as for instance dogs, which were domesticated, are only represented by teeth in ornaments, and suinae can be found both as food offerings and as canines in bracelets. Finally, it is interesting to raise the question of the significance of isolated bones, which are often considered intrusive: mandibles from suinae, isolated bones of cattle and small ruminants and even parts of birds, found in graves from the Paris basin, or fox mandibles in the wealthiest male graves from a Bavarian cemetery. Such apparently meaningless fragments had never attracted attention until the discovery of figurines on sheep metapodials in Linear Pottery Culture graves from the Paris basin und upper Alsace. These figurines all exhibit a glossy appearance and bear small white mother-of-pearl rings that are symmetrically placed on the distal portion of the metacarpus and represent the eyes. This discovery emphasizes the symbolic dimension of some small items (Jeunesse 1997).

The occurrence of animals in burial sites encompasses a considerable diversity of remains, the significance of which still remains to be understood. The strict opposition between meat quarters totally devoid of characteristic elements on the one hand, and animal representations based on small typical 
elements on the other illustrates the complexity of the relationships between fauna and funerary customs. Through their integration into grave good assemblages, animal bone remains thus constitute sensitive markers of the ideology of early and middle Neolithic communities.

\section{Acknowledgement}

We thank Marie Meister and Penny Bickle for her help in translation.

\section{REFERENCE}

ARbogast R.-M. 1994. - Premiers élevages néolithiques du Nord-Est de la France. ERAUL 67, Liège.

Boes E., Jeunesse C., Arbogast R.-M., Lefranc P., Mauvilly M., Schneikert F. \& Sidéra I. 2007. - Vendenheim "le Haut du Coteau" (Bas-Rhin) : remarques sur l'organisation interne d'une nécropople du Néolithique ancien danubien, in Besse M. (eds) Sociétés néolithiques. Des faits archéologiques aux fonctionnements socio-économiques. Actes du 27ème colloque interrégional sur le Néolithique (Neuchâtel 1 et 2 octobre 2005) Cahiers d'Archéologie Romande 108 : 279-283.

JeUNESSE C. 1997. - Pratiques funéraires au Néolithique ancien. Sépultures et nécropoles danubiennes. 5500-4900 av. J.-C. Editions Errance, Paris.

Jeunesse C. 2002. - Vendenheim "Le Haut du Coteau» une nécropole du Néolithique ancien: Document final de synthèse. Strasbourg, Service régional d'Archéologie.

Jeunesse C. \& Arbogast R.-M. 1997. - A propos du rôle de la chasse au Néolithique moyen. La faune sauvage dans les déchets domestiques et dans les mobiliers funéraires, in JEUNESSE C. (eds) Le Néolithique danubien et ses marges entre Rhin et Seine. Actes $d u$ 22ème colloque interrégional sur le Néolithique, Strasbourg, octobre 1995, 81-102.

KAHLKE D. 1954. - Die Bestattungssitten des donauländischen Kulturkreises der jüngeren Steinzeit. Teil I : Linearbandkeramik. Berlin 1954.

NiesZERY N. 1995. — Linearbandkeramische Gräberfelder in Bayern, Internationale Archäologie 16, Marie Leidorf Verlag, Espelkamp, 1995.

SPATZH. 1999. - Das mittelneolithische Gräberfeld von Trebur, Kreis Cross Gerau. Materialien zu Vor und Frühgeschichte Von Hessen 19. Wiesbaden, 1999.

Spatz H. \& Von Den Driesch A. 2001. - Zu den tierischen Beigaben aus dem Hinkelsteiner und Grossgartacher Gräberfeld von Trebur, Kr. Gross-Gerau. In Arbogast R.-M., Jeunesse C. \& Schibler J. (eds) Rôle et statut de la chasse dans le Néolithique ancien danubien (5500-4900 av. J.-C). Internationale Archäologie, Arbeitsgemeinschaft, Symposium, Tagung, Kongress, Marie Leidorf Verlag, Espelkamp, 114-128.

Guichard Y., FarRugGia J.P. \& HaChem L. 1996. — Les ensembles funéraires rubanés de Menneville "Derrière le Village” (Aisne). Actes du XVIII Colloque Interrégional sur le Néolithique, Dijon, oct. 1991: 119-174. 